\author{
Wielisława Warzywoda-Kruszyńska \\ University of Lodz, Faculty of Economics and Sociology, Department of Applied Sociology \\ and Social Work, zsoul@uni.lodz.pl
}

\author{
Kamil Kruszyński \\ University of Lodz, Faculty of Economics and Sociology, Department of Economic and Social \\ Statistics, kruk@uni.lodz.pl
}

\title{
Deprived Urban Neighbourhoods in Poland - Risk of Intergenerational Transmission of Poverty and Social Exclusion
}

\begin{abstract}
The paper applies to the problem of child poverty and social deprivation that scholars consider an obstacle for present and future development of society, as it is expressed in the concept of the social investment state. In the article, we discuss the issue in the context of neighbourhood effects approach since growing up in neglected communities is a risk factor for poverty perpetuation in the course of life and across generations. Because the small urban area statistics is unavailable in Poland, we provide results of sociological case study carried out in urban neglected neighbourhoods in Łódź. It enables to present the problem of child poverty through the lens of those affected by disadvantage. The broader context for the discussed problem offer results of analysis based on public statistics concerning dynamics of child poverty and social deprivation in Poland, as compared with other EU member states. Applying interdisciplinary approach, the article aims at getting better understanding of the phenomenon of poverty and social deprivation among children in Poland and its dynamics. We argue that temporal patterns of child poverty and social deprivation may be different in mainstream society approached in research based on representative samples and in poor population living in disadvantaged neighbourhoods. Therefore, we conclude that despite significant decrease in poverty and social deprivation among children, as documented by public statics, Poland is still a country where child poverty is a serious problem and where the grownups located at the bottom of social ladder are "children left behind".
\end{abstract}

Keywords: neighbourhood effects, child poverty and social deprivation, social inequalities among children.

JEL: R23 


\section{Introduction - the scientific problem, the goal of the article, specific questions and databases}

The paper applies to the problem of child poverty and social deprivation that scholars consider an obstacle for present and future development of society. It is expressed most clearly in the concept of the social investment state and its consequence known as investing in children approach. The article aims at gaining a better understanding of the phenomenon of poverty and social deprivation among children in Poland. The issue is discussed in the context of neighbourhood effects perspective because growing up in neglected communities is widely recognised as a risk factor for poverty perpetuation in the course of life and across generations.

To achieve the article's goal, interdisciplinary approach is applied to answer the following, specific questions:

1. How did Poland perform in the ten years of EU membership in tackling child poverty and social deprivation as compared to other EU member states?

2. What is the extent of poverty and social deprivation among children in Poland today?

3. How is poverty and social deprivation in childhood and adolescence experienced by grownups in disadvantaged neighbourhoods?

4. What does the study contribute to the scientific problem of child poverty and social deprivation?

5. Is knowledge based on statistical indicators sufficient enough for policies aiming to mitigate child poverty and social deprivation?

The article is based on two data sources:

1) Eurostat data set on "Investing in children",

2) sociological case study series carried out in Łódź's disadvantaged neighbourhoods (originally referred to as enclaves of poverty).

Following "Investing in children" indicators are analysed in the article:

1) at risk of poverty or social exclusion rate (AROPE),

2) at risk of poverty rate (AROP),

3) at risk of poverty rate anchored at a fixed moment in time (2008),

4) at risk of poverty rate anchored in 2005 ,

5) severe material deprivation rate,

6) severe housing deprivation rate,

7) persistent at risk of poverty rate.

Data on changes in above mentioned indicators in Poland are presented in comparison with:

1) the post-socialist EU member states,

2) an average for the UE-27,

3) Finland as the best performer in the matter in the year 2005 . 
Bearing in mind that changes in children's well-being took place in all EU member states in the period under scrutiny, an estimation of changes in Poland in relative terms allowed to categorise Poland as good, better or worse performer. Categories of countries mentioned above were selected for comparison reasons because: post-socialist member states share similar economic and socio-cultural heritage with Poland, the average for EU-27 constitutes a meaningful borderline dividing countries into good and bad performers, and Finland serves as a model to achieve.

Hypotheses underlying comparisons with above mentioned EU member states are as follows:

1. Poland shared the same tendency in the process of tackling child poverty and social deprivation as other post-socialist EU member states.

2. Poland improved its position in relation to the "average" in the EU-27 member states.

3. Poland improved its position in relation to the best performer.

Sociological research series carried out as a case study constitutes the second source of data used in the article. According to our best knowledge, the study is the only one in Poland in which disadvantaged neighbourhoods (originally called enclaves of poverty) have been delineated with a purpose to reveal urban areas strongly populated by the poor. In 1998 geographers co-working with sociologists delimited in Łódź 845 street blocks. For each of them, the poverty rate was calculated as proportion of members of households granted social assistance benefit (provided on the means test) among dwellers of a given street block. The area composed of at least two adjacent street blocks was called an enclave of poverty, when the poverty rate in each of the blocks was higher than 30 percent. Altogether 17 poverty enclaves were revealed within the city boundaries. 12 of them were located in the inner-city area (Grotowska-Leder, 1998). On average, every second child growing up there was a member of a household living on social assistance benefit, as compared with every third adult (Grotowska-Leder, 1998: 44). Ten years later, all 12 inner-city poverty enclaves were found within the boundaries of the child poverty enclaves, defined as elementary school districts with the proportion of pupils receiving free meals (offered on the means-tested rule) being at least twice as high as the average in the city (13\%). In two of them, every second child was provided with a free meal (Warzywoda-Kruszyńska, Petelewicz, 2010; Petelewicz, Rokicka, 2014).

In the article, we refer to the results of the qualitative study based on more than 120 family life stories, told by adults living in Łódź's enclaves of poverty in 1998 and 2008. The narrators were those who grew up in very low-income households, located in the above mentioned inner-city enclaves of poverty. They were themselves underinvested in childhood, and so are their children. Repre- 
sentatives of social services working in these localities were also asked to report on living and learning conditions in these areas. The citations presented in the paragraph 4 serve as manifestations of larger categories produced in the procedure of qualitative data elaboration. These categories go beyond poverty and social deprivation as defined by EUROSTAT investing in children indicators and cover, apart from housing and material deprivation, also health conditions and interpersonal relations that altogether impact on the academic achievements and broadly defined children's life opportunities.

The results of referred sociological research series were used as evidence-based data in strategic governmental (The National Plan for Combating Poverty and Social Exclusion 2020. New approach to social integration, 2014) and local (Social Policy 2020+ for the City of Łódź, 2014) official documents. They laid the foundations for the strategic municipal program of social revitalisation in Łódź, being (Local Revitalisation Strategy, 2016).

Combining results based on quantitative and qualitative methodology to get better understanding of social phenomena is strongly recommended by scholars using neighbourhood effects approach, as mentioned below in literature review. In the article it translates into the statement that temporal patterns of child poverty and social deprivation may be different in different populations. We argue that the decrease in child poverty documented in the mainstream society may be accompanied by petrification of poverty and risk of intergenerational transmission of social deprivations in poor population living in disadvantaged neighbourhoods.

The article contains three parts. It begins with a review of selected literature on neighbourhood effects and investing in children. Then the results of analysis of child poverty dynamics in Poland, as compared with post-socialist EU member states, EU-27 countries and with Finland, is presented. The third paragraph documents child poverty and social deprivation as experienced by people growing up in disadvantaged neighbourhoods in Łódź. Conclusions contain short summarising of the research results.

\section{Review of selected literature on neighbourhood effects and investment in children}

The best and most efficient way to invest in the future of the society is investing in children. They should be protected against adverse neighbourhood effects resulting in intergenerational transmission of poverty.

The foundation for neighbourhood effects research based on an assumption of an independent residential and social environment impact on life opportunities of individuals was laid in William Justus Wilson's book “The Truly Disad- 
vantaged: The Inner City, the Underclass and Public Policy" (1987). Since then, research on the issue is blossoming in USA and Western Europe. Starting in the 1990s, it attracted the attention of economists, geographers, and sociologists, using quantitative methods to analyse statistical correlations between neighbourhood deprivation and outcomes of individuals (Durlauf, 2004; van Ham et al., 2012). They seem to have laid the foundation for local policies aimed at tackling social deprivation. In the UK, Labour Party government addressed public programs to the disadvantaged communities. Area-based policies to socially mix populations were practised in the USA (Moving to Opportunity Program in Chicago) and European cities (Atkinson, Kintrea, 2002; Kearns, 2002; Musterd, 2002).

Recent literature reviews (van Ham et al., 2012) claim that quantitative neighbourhood effects research is at "a crossroads". Ethnographic qualitative methods are recommended to better understand causal relations in disadvantaged communities (Small, Feldman, 2012).

Therefore, another strand in research aimed at explaining neighbourhood effects, based on qualitative sociological methods, gained significance. According to Lupton (2003: 41), this is because this particular approach:

1) conceptualises neighbourhood as people and places, which means that it takes into account interrelation between physical and social environment,

2) considers neighbourhood as having different boundaries for various categories of residents who may experience neighbourhood impact differently, and

3) emphasises that neighbourhoods are embedded in broader socio-economic-cultural context.

Therefore, such approach attempts to provide theoretical proposals to explain existence and persistence of disadvantaged neighbourhoods.

Although it is a host of accounts on social deprivation and poverty persistence in disadvantaged urban areas, a geographical cover of such research is rather uneven. Long lasting interest in concentrated poverty in USA cities, resulted in an abundance of investigations and competing theories (Lewis, 1966a; 1966b; Wilson, 1987; Wacquant, 2007a; Sampson, 2009). Nowadays the contradiction between culture and structures as drivers and maintainers of poverty reproduction is not as profound as it used to be before (Duvoux, 2010; Harding, Lamont, Small, 2010; Wilson, 2010).

In Western Europe, among scholars an opinion prevails that the situation in European cities is different regarding ethnic relations and impact of business (Kazepov, 2009) and incomparable with the present situation in the USA (e.g. Morris, 1994; Marshall, Roberts, Burgoyne, 1996; Morris, Scott, 1996; Body-Gendrot, 2007). However, after violent riots in France some years ago, there are also stances that Zones Urbaines Sensibles have developed in the course of 1990s, with many characteristics resembling African-American ghetto (Stébé, Marchal, 2009).

Loic Wacquant, a very eminent scholar, formulated a theory providing the explanation for disadvantaged neighbourhoods existing in both the USA and the Eu- 
ropean cities. He claims that: "The comparative sociology of the structure, dynamics, and experience of urban relegation in the United States and the European Union during the past three decades reveals the emergence of a new regime of marginality. This regime generates forms of poverty that are neither residual, nor cyclical or transitional, but inscribed in the future of contemporary societies insofar as they are fed by the ongoing fragmentation of the wage labour relationship, the functional disconnection of dispossessed neighbourhoods from the national and global economies, and the reconfiguration of the welfare state in the polarizing city" (2007a: 66). He argues that poverty perpetuation in neglected neighbourhoods, called by him the neighbourhoods of relegation, results from changes undergoing in globalised capitalism. Contemporary capitalism has created a particular form of poverty being advanced marginality whose emanation is a neighbourhood of relegation. Such neighbourhoods are characterised by:

1) territorial stigmatisation,

2) the transformation from being "the place" of residence as a form of collective life modus to "space" where individuals are disconnected, and

3) having no viable hinterland.

Such neighbourhoods have been pushed onto the margin of society and relegated from the profits resulting from a city development. Antisocial behaviours observed there result from precarious employment and lack of opportunities for the relegated.

Wacquant's theory, though controversial, offers excellent departure point for thinking about disadvantaged areas in other places of Europe, such as Central and Eastern Europe. However, among CEE scholars (Sykora, 2009; Temelová et al., 2011; Cirman et al., 2013; Kovacs et al., 2013; Krisjane, Berzins, 2014; Marcińczak et al., 2014) an opinion prevails that the CEE cities are not socially segregated, which results from housing politics based on the rule of social mix. However, qualitative research carried out in Romania (Stănculescu, Berevoescu, 2004) and Poland (Warzywoda-Kruszyńska, 1998; 1999; 2010; Warzywoda-Kruszyńska, Potoczna, 2009; Warzywoda-Kruszyńska, Jankowski, 2013), introduces some doubts about such conclusions.

A crucial element in poverty perpetuation in disadvantaged neighbourhoods are children. Scholars in the USA devoted vast amount of research to better understand the impact of poverty on child development (e.g. Duncan, Brooks-Gunn, 1997; Sen, 1999; Schonkoff, Phillips, 2000; Chase-Lansdale, Kiernan, Friedman, 2004). A long-lasting disagreement existed among scholars, about what causes poor children to perform worse at school than their better-off peers: nature or nurture. Recently the opinion prevails, that "it is not nature versus nurture but nature through nurture" (Schonkoff, Phillips, 2000: 41).

The concept of the social investment state formulated by Anthony Giddens's (1998) combined, to some extent, the neighbourhood effects approach with ac- 
counts on poverty's impact on child development. According to him, the state should act as an entrepreneur aiming at receiving the highest gains from public spending. So, it should invest in such social groups and activities that promise the highest pay-off. Therefore, human capital development should be the focus of government interest and children should be deemed the first group in which to invest. Gosta Esping-Andersen (2005) formulated explicit reference to childhood as the central element of the social investment state. Focusing on child care and education would reward society in two ways: by increased productivity due to increased women's employment and by preventing inequality from continuing into the next generation.

James Heckman ${ }^{1}$ with his team produced the "hard" proof supporting the above claim (Conti, Heckman, 2012). They provided evidence that investing in children is economically most efficient. Heckman (2006) stated that investing in children and youth generates a higher return rate on investment than investing in adults. Investment in small children produces the highest benefit-cost ratio and rate of return because during early childhood the most rapid development of the brain occurs. The skills acquired at this stage beget other skills and learning begets learning.

Policy-makers, both on international and national levels, applauded the concept of social investment. The European Commission published on February 20, 2013, a Recommendation titled: "Investing in Children. Breaking the Cycle of Disadvantage". Eurostat provides commonly agreed indicators, measuring progress in investing in children in member states. However, non-profit organisations, such as Eurochild, observing how the Recommendation has been put into practice, keeps raising alarm that investing in children remains rather a declarations than a practice (Eurochild, 2015).

Very few EU member states reacted to the Recommendation making specific commitments to address children at risk of poverty or social exclusion. Poland is among the ones who did. In August 2014 Polish government launched The National Plan for Combating Poverty and Social Exclusion 2020. One of the five operational goals of the plan focuses on reducing child poverty and social exclusion, yet without specifying the national target. Until then child poverty and social exclusion were not on the government agenda. Notwithstanding, in the last ten years, Poland has made considerable progress in reducing poverty among children, as documented by indicators applying to the "average" situation in the country. However, when one goes any deeper, the picture becomes less optimistic.

\footnotetext{
${ }^{1}$ Nobel Prize winner in economy in 2000.
} 


\section{Dynamics of child poverty and social exclusion in Poland as compared with EU-27 average, the post-socialist EU member states, and Finland - the best performer in 2005}

The Innocenti Report (UNICEF, 2005: 12) documented that in the 1990s, Poland was the state, among OECD countries, where the relative number of children living in poverty increased most steeply - by 6.1 p.p.

In 2005 (the first year of Poland's membership in the European Union), nearly every second child (48\%) suffered from poverty or social exclusion. Child poverty was documented at $29 \%$, which located Poland in the last place in the EU-252. After having joined the European Union, the well-being of children in Poland significantly improved (Table 1). As compared to 2005:

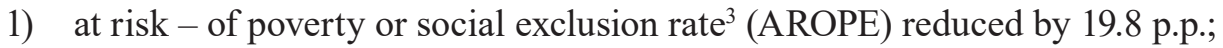

2) at risk of poverty rate rey $^{4}$ p.p.;

3) at risk of poverty rate anchored at a fixed moment in time ${ }^{5}(2008)$ - by 14.5 p.p.;

4) at risk of poverty rate anchored in 2005 - by 15.4 p.p.;

5) severe material deprivation rate $^{6}-$ by 26.2 p.p.;

6) severe housing deprivation rate $^{7}-$ by 24.8 p.p.;

7) persistent at risk of poverty rate $^{8}-$ by 2.3 p.p.

2 There were then 25 member states in the European Union.

3 The AROPE rate, refers to the situation of people either at risk of poverty, or severely materially deprived or living in a household with a very low work intensity.

${ }_{4}$ The at-risk-of-poverty rate is the share of people with an equivalised disposable income (after social transfer) below the at-risk-of-poverty threshold, which is set at $60 \%$ of the national median equivalised disposable income after social transfers. The relative child poverty rate "shows the proportion of children who are to some significant extent excluded from the advantages and opportunities which most children in that particular society would consider normal" - UNICEF, 2013: 8.

5 The indicator is defined as the percentage of the population whose equivalised disposable income is below the 'at-risk-of-poverty threshold' calculated in the standard way for the base year, currently 2005 or 2008 , and then adjusted for inflation.

${ }^{6}$ Severe material deprivation rate is defined as the enforced inability to pay for at least four of the below-mentioned items: (1) to pay their rent, mortgage or utility bills; (2) to keep their home adequately warm; (3) to face unexpected expenses; (4) to eat meat or proteins regularly; (5) to go on holiday; (6) a television set; (7) a washing machine; (8) a car; (9) a telephone.

${ }^{7}$ Severe housing deprivation rate is defined as the percentage of population living in dwellings which are considered overcrowded, while also exhibiting at least one of the housing deprivation measures: leaking roof, no bath/shower and no indoor toilet, or a dwelling considered too dark.

${ }^{8}$ The persistent at-risk-of-poverty rate shows the percentage of the population living in households where the equivalised disposable income was below the at-risk-of-poverty threshold for the current year and at least two out of the preceding three years. Its calculation requires a longitudinal instrument, through which the individuals are followed over four years. 
Regarding the fall of incidence of child poverty and social deprivation among children, Poland was in the period 2005-2014 the best performer among the EU member states, including post-socialist ones in which an improvement was also noticed. (Table 1) Poland was the only EU member state where downward tendency occurred in all examined social deprivation areas.

Table 1. Changes in Investing in children indicators in the post-socialist EU Member States (2014-2005)

\begin{tabular}{|l|c|c|c|c|c|c|c|c|}
\hline \multicolumn{1}{|c|}{ State } & $\begin{array}{c}\text { At risk } \\
\text { of poverty } \\
\text { rate }\end{array}$ & $\begin{array}{c}\text { At risk } \\
\text { of poverty } \\
\text { rate } \\
\text { or social } \\
\text { exclusion }\end{array}$ & $\begin{array}{c}\text { Severe } \\
\text { material } \\
\text { deprivation }\end{array}$ & $\begin{array}{c}\text { At risk } \\
\text { of poverty } \\
\text { rate } \\
\text { anchored } \\
\text { (2008) }\end{array}$ & $\begin{array}{c}\text { At risk } \\
\text { of poverty } \\
\text { rate } \\
\text { anchored } \\
\text { (2005) }\end{array}$ & $\begin{array}{c}\text { Relative } \\
\text { at risk } \\
\text { of poverty } \\
\text { gap }\end{array}$ & $\begin{array}{c}\text { Persistent } \\
\text { at risk } \\
\text { of poverty } \\
\text { rate }\end{array}$ & $\begin{array}{c}\text { Severe } \\
\text { housing } \\
\text { deprivation }\end{array}$ \\
\hline Bulgaria & +0.4 & -15.8 & $-22.0^{\mathrm{a}}$ & +1.2 & na & +7.0 & +9.5 & -7.0 \\
\hline $\begin{array}{l}\text { Czech } \\
\text { Rep. }\end{array}$ & -2.0 & -6.1 & $-5.6^{\mathrm{b}}$ & +1.0 & -6.2 & +2.7 & -0.3 & -8.8 \\
\hline Estonia & -1.6 & -4.6 & $-8.7^{\mathrm{c}}$ & +2.3 & -6.7 & -1.0 & +1.6 & -17.1 \\
\hline Latvia & +2.3 & -10.4 & $-19.8^{\mathrm{c}}$ & +7.2 & -12.5 & -2.3 & +0.7 & -18.9 \\
\hline Lithuania & -3.7 & -13.9 & $-18.4^{\mathrm{c}}$ & +3.7 & -11.3 & -3.5 & +8.5 & -22.1 \\
\hline Hungary & +5.1 & +3.4 & $-2.6^{\mathrm{c}}$ & +9.0 & +0.4 & +3.7 & 0 & -3.7 \\
\hline Poland & -7.0 & -19.8 & $-26.3^{\mathrm{c}}$ & -7.1 & -15.4 & -8.2 & -2.3 & -24.8 \\
\hline Romania & +6.6 & -3.7 & $-10.0^{\mathrm{d}}$ & +2.0 & na & +0.4 & +0.2 & -11.5 \\
\hline Slovenia & +2.7 & +2.4 & +0.5 & +6.0 & +2.0 & +6.7 & +4.1 & +1.4 \\
\hline Slovakia & +0.3 & -11.4 & -11.5 & -3.5 & -7.7 & +7.9 & +1.6 & -1.3 \\
\hline
\end{tabular}

Source: own calculations based on Eurostat (http://ec.europa.eu/eurostat/web/employment-and-social-inclusion-indicators/social-protection-and-inclusion/investing-children). For Bulgaria and Romania calculations cover the years 2007 and 2014

In the course of 2000s, the position of Poland in relation to the EU-27 changed impressively. Whereas in 2005 Polish children suffered much more frequently from deprivation and poverty than their peers did on average in the EU-27, in 2014 the difference reduced almost entirely (Table 2).

Table 2. Differences between Poland and the EU-27 in the proportion of children suffering from poverty and deprivation (in \%)

\begin{tabular}{|c|c|c|c|c|c|c|c|c|}
\hline Year & $\begin{array}{c}\text { At risk } \\
\text { of poverty } \\
\text { rate }\end{array}$ & $\begin{array}{c}\text { At risk } \\
\text { of poverty } \\
\text { rate } \\
\text { or social } \\
\text { exclusion }\end{array}$ & $\begin{array}{c}\text { Severe } \\
\text { material } \\
\text { deprivation } \\
\text { rate }\end{array}$ & $\begin{array}{c}\text { At risk } \\
\text { of poverty } \\
\text { rate } \\
\text { anchored } \\
\text { (2008) }\end{array}$ & $\begin{array}{c}\text { At risk } \\
\text { of poverty } \\
\text { rate } \\
\text { anchored } \\
\text { (2005) }\end{array}$ & $\begin{array}{c}\text { Relative } \\
\text { at risk } \\
\text { of poverty } \\
\text { gap }\end{array}$ & $\begin{array}{c}\text { Persistent } \\
\text { at risk } \\
\text { of poverty } \\
\text { rate }\end{array}$ & $\begin{array}{c}\text { Severe } \\
\text { housing } \\
\text { deprivation } \\
\text { rate }\end{array}$ \\
\hline 2005 & $+6.3^{\text {a }}$ & +20.0 & +22.1 & $+12.1^{\text {b }}$ & na & +8.5 & $+5.0^{\mathrm{b}}$ & +24.7 \\
\hline 2014 & +1.2 & +0.5 & +0.1 & -8.2 & na & -1.9 & +0.3 & +3.8 \\
\hline
\end{tabular}

Source: own calculation based on Eurostat (http://ec.europa.eu/eurostat/web/employment-and-social-inclusion-indicators/social-protection-and-inclusion/investing-children) 
Therefore, in 2014 the country placed close to the EU-27 average. Values of following indicators are similar for the EU-27 and Poland:

1) at risk - of poverty or social exclusion rate $-27.7 \%$ versus $28.2 \%$;

2) severe material deprivation rate $-10.2 \%$ versus $10.3 \%$;

3) at risk of poverty rate $-21.1 \%$ versus $22.3 \%$;

4) persistent at risk of poverty rate $-13.2 \%$ versus $13.5 \%$.

The relative at risk of poverty gap occurred even slightly lower in Poland $-26.2 \%$ v. $24.3 \%$, and at risk of poverty rate anchored in 2008 was much lower than for EU-27 - 23.5\%. v 15.3\%. However, despite substantial progress in housing conditions, Poland was still behind EU-27 average. The proportion of children suffering from severe housing deprivation was 3.8 p.p. higher than in EU-27.

Though these numbers are impressive, we have to bear in mind that EU average results from different tendencies in tackling child poverty and social deprivation in particular member states and that poverty threshold is relative ${ }^{9}$ and country specific. There is a huge gap regarding income set as poverty lines between "old" EU members and those having joined the EU at the beginning of 21st century ${ }^{10}$. The last economic crisis resulted in lowering of incomes in several countries and a growing extent of poverty. A comprehensive analysis of the impact of the crisis on children's well-being is provided by a report by Natali, Martorano, Handa, Holmqvist, Chzhen (2014). Therefore, though impressive, comparisons with EU27 average should be considered with caution.

Instead, comparison with Finland, which in 2005 was the state having the lowest child poverty or social exclusion rate (15\%), is less doubtful. It confirms the progress made in Poland in the last ten years. Though still, relatively more children in Poland than in Finland suffer from poverty and social deprivation, the gap reduced very substantially, particularly regarding housing and material conditions (Table 3).

Therefore, the state of affair is, as before, far from satisfactory despite the progress made. In 2014, more than every fourth child in Poland was at risk of poverty or social exclusion, more than every fifth lived in poverty, more than every seventh suffered from persistent poverty. What is more, OECD data document (UNICEF, 2016) massive inequality in material well-being among children in Poland, as measured at the bottom end of the distribution ${ }^{11}$. In 2014, the child at the 10th percentile had less than half the disposable household income of the child

9 This threshold defines low income in comparison to other residents in the country. It is set at $60 \%$ of the national median equivalised disposable income after social transfers. (metadata - Eurostat).

${ }^{10}$ In 2005 it was: in Luxemburg 16.538 and in Lithuania 2.308; in 2014 in Luxemburg 16.818 and in Romania 2.439.

${ }^{11}$ To measure inequality at the bottom end of the distribution, the household income of the child at the 50th percentile (the median) is compared with the household income of the child at the $10^{\text {th }}$ percentile (i.e. poorer than 90 per cent of children); the gap between the two, reported as a per- 
at the median, whereas in Norway, being the best performer, it had less than 37 p.p. In Romania, being the worst performer it was less than 67 p.p. Poland ranks 23 among 37 countries under scrutiny.

Table 3. Differences between Poland and Finland in the proportion of children suffering from poverty and deprivation (in \%)

\begin{tabular}{|c|c|c|c|c|c|c|c|c|}
\hline Year & $\begin{array}{c}\text { At risk } \\
\text { of poverty } \\
\text { rate }\end{array}$ & $\begin{array}{c}\text { At risk } \\
\text { of poverty } \\
\text { rate } \\
\text { or social } \\
\text { exclusion }\end{array}$ & $\begin{array}{c}\text { Severe } \\
\text { material } \\
\text { deprivation } \\
\text { rate }\end{array}$ & $\begin{array}{c}\text { At risk } \\
\text { of poverty } \\
\text { rate } \\
\text { anchored } \\
\text { (2008) }\end{array}$ & $\begin{array}{c}\text { At risk } \\
\text { of poverty } \\
\text { rate } \\
\text { anchored } \\
\text { (2005) }\end{array}$ & $\begin{array}{c}\text { Relative } \\
\text { at risk } \\
\text { of poverty } \\
\text { gap }\end{array}$ & $\begin{array}{c}\text { Persistent } \\
\text { at risk } \\
\text { of poverty } \\
\text { rate }\end{array}$ & $\begin{array}{c}\text { Severe } \\
\text { housing } \\
\text { deprivation } \\
\text { rate }\end{array}$ \\
\hline 2005 & $+16.5^{\text {a }}$ & +33.0 & +30.4 & $+10.4^{\mathrm{b}}$ & $+14.4^{\mathrm{a}}$ & +20.6 & $+11.9^{\mathrm{b}}$ & +34.9 \\
\hline 2014 & +11.4 & +12.6 & +8.2 & +5.8 & +0.9 & +12.5 & +7.7 & +11.0 \\
\hline
\end{tabular}

Source: own calculation based on Eurostat (http://ec.europa.eu/eurostat/web/employment-and-social-inclusion-indicators/social-protection-and-inclusion/investing-children)

In 2014, children accounted for 35\% of people living in households provided with means-tested social assistance benefit (GUS, 2015a: 44), which means massive overrepresentation of children among the disadvantaged population ${ }^{12}$. These are the children living in poor families and labelled "children left behind" (UNICEF, 2010). Among them, there are those who grow up in poor households residing in disadvantaged neighbourhoods.

\section{Growing up in disadvantaged urban neighbourhoods (the example of Łódź)}

Enclaves of poverty in Łódź unlike African-American ghettos in North America, Zones Urbanes Sensibles in France or Roma ghettos in Romania are not isolated areas regarding ethnicity and transportation. What at first glance makes these places different from other real estates in the city is the devastation of buildings and spaces, visible disorder and signs of antisocial behaviour. These physical characteristics accompanied by concentration of poor population attaches stigma to these localities and people living there (Jankowski, Warzywoda-Kruszyńska, 2015: 106).

In these areas, there are extremely run down, tenant houses constructed at the beginning of the 20th century. Poorly built and lacking sanitary installations, they

centage of the median, provides us with a measure of how far behind the poorest children are being allowed to fall (UNICEF, 2016: 5). 2015b).

${ }^{12}$ The share of children in the total population in Poland in 2014 ammounted to 18\% (GUS, 
were extremely underinvested at the time of socialism. In the 1960s and 1970s, new housing complexes were erected in Łódź far from the city centre at the expense of the maintenance of the existing resources. It was at that time when the first wave of better-off dwellers moved out to the panel block settlements. The decay of tenant houses accelerated when in the 1990s the municipal administration established social housing ${ }^{13}$ in the inner-city buildings, for individuals and families evicted from previous flats because they had fallen into arrears in rent, were ex-prisoners, were young adults leaving residential care institutions, including young mothers and others unable to maintain usual housing costs as a consequence of vast unemployment. Apart from administrative decisions to settle families and individuals with low or no income in the inner-city areas, it was also a spontaneous outflow of better-off residents and inflow of those who were no longer able to pay rent for apartments in panel block flats and decided to move to these areas to prevent eviction.

Settlements such as described above are not an appropriate physical or social environment for children and teenagers to grow up in. Severe housing deprivation, health problems, destroyed family relations and a lack of role models make adolescents from very low income families embedded in poor neighbourhoods drop out of school and thus follow the life path of their parents.

A nurse who visits families in poverty enclaves described buildings located there as follows:

[...] It is extreme, so you could just say, well, because of the filth, stench, and poverty [...] The old building without amenities, most frequently one-room flats, really [you] do not have [a place for] a chair to sit on, no hot water; some have gas, some are disconnected. Half of [the residents of] the building is pulling electricity illegally. There are toilets in some parts of the building, and some are shared on the corridor [...] [sometimes] WC [is] outside the building... However, do not touch the stairwells, be careful, because you can kill yourself, slippery, dirty, not cleaned.

Many inhabitants of such buildings are in debt and have fallen into arrears. Therefore, their flats got disconnected from electricity and gas. The narrator who was a child at the turn of the 2000 s reports:

[When I was a child] I had no electricity [...], there was no TV, no lights [...] because of arrears. They disconnected us [also] from gas [...] I remember that electricity was disconnected for five or six years [...] and it was necessary to do

${ }^{13}$ The standard for such shelter is 5 square meters per person. It should be equipped with an oven and cold running water. 
homework as soon as possible [after coming back from school] so that later we wouldn't have to bother with candles.

A mother of two school-aged children, living in a flat without hot water or a shower, worried first of all about power disconnection. The power company uninstalled the electricity metre in her apartment, which is a standard practice of such companies towards clients having arrears.

I do not have [in my flat] these essential amenities that children should have. They should have a bath or at least a shower, hot water so that they can take a bath [...] [But] for now I want to do this as soon as possible just, just to have electricity metre installed [...].

Like many other dwellers in the area, she has an illegal power connection in the flat. The installation is makeshift, and she worries that one day it will not work well, which would hinder her children doing homework and playing.

In many buildings, walls are wet and covered with mildew as reported by a female narrator:

[...] Municipal housing administration does not invest in these buildings at all

[...] There is mildew everywhere on walls, not only gable walls but also inside walls $[\ldots]$.

Living in substandard housing conditions makes children isolated from and bullied by classmates. A teacher said to us:

[when] at home there is dirt [...] [then] clothes [of a child] are soaked with the smell of mildew, [...] or moisture, or sometimes the children are dirty, often neurotic. For example, well, kind of smell like piss [...] Moreover, these children are perceived by the rest of the class as 'the others' [...].

Pupils from destitute families are also perceived by classmates as 'different' because they do not share with them experiences connected to participation in school trips or other paid activities organised by the school. School counsellor explained:

[...] The truth is, that if you need to organise a fundraiser, for example, for a trip outside Łódź, [...] there is a large group of children in the class, who cannot afford it [...] Poorer children stay at school or are released from classes, or someone does something with them. It is the terrible truth about the Polish school. 
For students whose school achievements are below those of other classmates, "regular" schools propose to transfer them to schools for pupils with specific educational needs. A mother of a 9-year old boy told us:

He attended elementary school [...] a regular school [...] well, and could not cope [...] The psychologist did not give him a referral to a special school [...] [But] a teacher says, [...] 'I have thirty-three students, I cannot, as in these schools [where] there are fewer pupils, [work] with each child individually'.

The teacher advised the woman, contrary to the opinion of a psychologist, to register her son in a special school for disabled pupils. The boy was admitted at her request, instead of being provided with extra tuition in his local school. Unfortunately, this is not an isolated incident but a practice frequently applied to poor children with learning difficulties. In many families under scrutiny, there were children in subsequent generations attending special schools.

There are many reasons for poor academic achievements of poor children living in poverty enclaves, including stress resulting from family relations (alcoholism, mental illness, violence), excessive household chores and care for siblings, earning a living and so forth.

Teenagers suffering from multidimensional deprivation are perceived as being "worse" (less respected), as a young man admitted:

[...] I was treated worse [by schoolmates] because I did not have branded clothes

[...] I did not look like my peers, provided with everything by their parents. [...] I did not take sandwiches to school, and I had no money to buy crisps in the store and so on [...]. I realized that I was not able to match them financially [...].

Because of informal "relegation" from schoolmates' circle, poor adolescents have to stick together with peers similar to them regarding socio-economic status and shared living experiences, in order to save self-esteem. They get exposed to adverse influences from peers and adults living in degraded neighbourhoods and violating generally respected rules. Typically, truancy is the beginning of the process leading to more severe deficits and dysfunctions, including expelling from school and eventually dropping out of school. Young women explained:

"When I hadn't done homework, I preferred not to go to school to avoid a bad mark." However, [...] later there were more serious problems with me [...] Well, I began [...] all sorts of drugs [...] I know that many people distribute and take drugs $[\ldots]$. 


\section{A young man recalled:}

[...] Well, I studied very, very well [in elementary school], but not later [after moving into a poverty enclave]. As I said, colleagues, marijuana, alcohol, for me it was more important than school [...].

Teenage boys are exposed to criminal activities and in consequence, some of them become prisoners as adults, like the son of one of the narrators. She said that her teenage son fell into bad company including a woman in her thirties, her lover and teenagers who were attracted by the woman:

[...] he [the son of the narrator, visited her and] ...started there with drugs. But, what could I do? I had my house searched [by the police] several times because they were looking for drugs or some stolen things ... [he was sentenced as a teenager and later on] and in the end one suspended sentence, the next suspended sentence, they got accumulated and he went to jail for 5 years and that's that $[\ldots]$.

A young woman reported:

[...] I have met people who came here to stay, they were cool $[. .$.$] here... here$ really, well, you cannot live. Here... everyone exerts pressure on other people to ruin their lives. Even unconsciously [...].

Sometimes a consequence of such relations is a teenage pregnancy leading to unfinished education and a long-lasting welfare dependency.

Comprehensive analysis of teenagers' exposure to social exclusion, based on the same research series, is presented by Agnieszka Golczyńska-Grondas (2015).

Poor children living in disadvantaged neighbourhoods constitute a link in the chain of poverty perpetuation and in its transmission to the subsequent generation. Poor parents produce poor children, who, as adults, produce next generation of socially disadvantaged individuals.

\section{Conclusions}

The article provided knowledge about child poverty and social deprivation in Poland and its dynamics in the context of neighbourhood effects and investing in children approaches. 
We argued that temporal patterns of child poverty and social deprivation are different in mainstream society and in poor population living in disadvantaged neighbourhoods.

Data on the dynamics of child poverty and social deprivation in Poland, as compared with post-socialist EU member states, the average for the UE-27 and Finland - the best performer in the matter, were presented. They documented impressive progress made by the country after joining the European Union in 2004. However, the problem of child poverty and social exclusion is still severe in Poland. Every fifth young Pole is at risk of poverty and $28 \%$ are at risk of poverty or social exclusion. Every third person in a household receiving social assistance benefit is under 18 years of age. Particularly, socially deprived are children in very low-income families, residing in disadvantaged neighbourhoods. People growing up in families living on welfare benefits are those addressed in UNICEF report as "children left behind". These children are those who are primarily exposed to the adverse impact of the disadvantaged neighbourhood and require much more investment than others. Using data produced in the sociological qualitative case study carried out in Łódź's enclaves of poverty, it was demonstrated that poverty petrified there. Such areas resemble Waquant's neighbourhoods of relegation that do not benefit from city development and exist on the margin of economic and social processes acting in the mainstream of society.

There is no doubt that the governmental program 500+ will contribute to a lowering of the monetary poverty in such places, even though this is not declared as a purpose of the program. However, the monetary help should be accompanied by extensive social work with families at the bottom of the social ladder, further development of early education and care institutions and social revitalization of areas in crisis.

\section{References}

"British Journal of Sociology" (2009), vol. 60, Issue 1.

A Multidimensional Approach to Measuring Child Poverty (2011), http://www.unicef.org/socialpolicy/files/A_Multidimensional_Approach_to_Measuring_Child_Poverty(2).pdf [accessed: 29.07.2016].

Atkinson R., Kintrea K. (2002), A consideration of the implications of area effects for British housing and regeneration policy, "European Journal of Housing Policy", no. 2(2), pp. 1-20.

Body-Gendrot S. (2007), La spécificité des ghettos noirs américains, "Urbanisme", no. 356, pp. 87-88. Bradshaw J. (2006), Child Poverty and Child Well-Being, a paper presented at the Social Policy Association Conference, University of Birmingham, July 2006, available from the Social Policy Research Unit, University of York, Helsington.

Brooks-Gunn J. (2004), Intervention and policy as change agents for young children, [in:] P.L. Chase-Lansdale, K.E. Kiernan, R.J. Friedman (eds.), Human Development Across Lives and Generations:The Potential For Change, Cambridge University Press, Cambridge.

Chase-Lansdale P.L., Kiernan K., Friedman R.J. (2004), Human development across lives and generations. The potential for change, Cambridge University Press, New York. 
Cirman A., Mandic S., Zoric J. (2013), Decisions to Renovate: Identifying Key Determinants in Central and Eastern European Post-socialist Countries, "Urban Studies", no. 50(16), pp. 3378-3393.

Conti G., Heckman J.J. (2012), The Economics of Child Well-Being, IZA Discussion Paper No. 6930.

Duncan G.J., Brooks-Gunn J. (eds.) (1997), Consequences of Growing Up Poor, Russell Sage Foundation, New York.

Durlauf S. (2004), Neighborhood effects, [in:] J.V. Henderson, J.F. Tisse (eds.), Handbook of Urban and Regional Economics, vol. IV, Elsevier, Amsterdam.

Duvoux N. (2010), The culture of poverty reconsidered, http://www.booksandideas.net/IMG/ pdf/20101005 duvoux EN.pdf [accessed: 29.07.2016].

Esping-Andersen G. (2005) Children in the welfare state. A social investment approach, DemoSoc Working Paper No. 2005-10, Universitat Pompeu Fabra, Barcelona.

Eurochild Working Paper (2015), A child-centered investment strategy. Why the Investment Plan for Europe needs to prioritise children.

Farah M., Noble K.G., Hurt H. (2009), Poverty, Privilege and Brain Development. Empirical Findings and Ethical Implications, http://www.psych.upenn.edu/ mfarah/farah_SES_05.pdf [accessed: 29.07.2016].

Giddens A. (1998), The Third Way. The Renewal of Social Democracy, The Polity Press, Cambridge.

Golczyńska-Grondas A. (2015), Nastolatki zagrożone wykluczeniem społecznym w Polsce 2014 w kontekście Zalecenia Komisji Europejskiej - Inwestowanie w dzieci: przerwanie cyklu marginalizacji, http://www.eapn.org.pl/publikacje/ekspertyzy/ [accessed: 29.07.2016].

Grotowska-Leder J. (1998), Łódzkie enklawy biedy, [in:] W. Warzywoda-Kruszyńska (ed.), Żyć i pracować w enklawach biedy, Instytut Socjologii Uniwersytetu Łódzkiego, Łódź.

GUS (2015a), Beneficjenci pomocy społecznej i świadczeń rodzinnych w 2014 r. Kraków.

GUS (2015b), Rocznik Demograficzny 2015, http://stat.gov.pl/download/gfx/portalinformacyjny/ pl/defaultaktualnosci/5515/3/9/1/rocznik_demograficzny_2015.pdf [accessed: 29.07.2016].

Jankowski B., Warzywoda-Kruszyńska W. (2015), Ciagłość i zmiana w łódzkich enklawach biedy, Wydawnictwo Uniwersytetu Łódzkiego, Łódź.

Ham M. van, Manley D., Bailey N., Simpson L., Maclennan D. (eds.) (2012), Neighbourhood Effects Research: New Perspectives, Springer, Dordrecht.

Harding D.J., Lamont M., Small M.L. (eds.) (2010), Reconsidering Culture and Poverty, "The Annals of the American Academy of Political and Social Science", vol. 629, pp. 6-27.

Harper C., Marcus R., Moore K. (2003), Enduring poverty and the conditions of childhood: life course and intergenerational poverty transmissions, "World Development", no. 31(3), pp. 535-554.

Heckman J. (2006), Investing in Disadvantaged Young Children is an Economically Efficient Poli$c y$, the presentation at the Committee for Economic Development/The Pew Charitable Trusts/ PPNC Financial Services Group Forum on "Building the Economic Case for Investment in Preschool", New York.

Kazepov Y. (ed.) (2009), Cities of Europe. Changing Contexts, Local Arrangements, and the Challenge to Urban Cohesion, Blackwell Publishing, Oxford.

Kearns A. (2002), Response: from residential disadvantage to opportunity? Reflections on British and European policy and research, "Housing Studies", no. 17(1), pp. 145-150.

Kovacs Z., Wiessner R., Zischner R. (2013), Urban Renewal in the Inner City of Budapest:Gentrification from a Postsocialist Perspective, "Urban Studies", no. 50, pp. 22-38.

Krajowy Program Przeciwdziałania Ubóstwu i Wykluczeniu Społecznemu 2020. Nowy wymiar aktywnej integracji [The National Plan for Combating Poverty and Social Exclusion 2020. New approach to social integration], Ministerstwo Pracy i Polityki Społecznej, Warszawa 2014.

Krisjane Z., Berzins M. (2014), Intra-urban residential differentiation in the post-Soviet city: the case of Riga, Latvia, "Hungarian Geographical Bulletin", no. 63, pp. 235-253. 
Lamont M., Small M.L. (2008), How Culture Matters: Enriching our Understanding of Poverty, [in:] A.C. Lin, D.R. Harris (eds.), The Colors of Poverty, Russell Sage Foundation, New York, http:// home.uchicago.edu/ mariosmall/documents/LamontSmall2008.pdf [accessed: 29.07.2016].

Lewis O. (1966a), La Vida: A Puerto Rican Family in the Culture of Poverty, Random House, New York.

Lewis O. (1966b), The Culture of Poverty, "Scientific American”, no. 215, pp. 19-25.

Lokalny Program Rewitalizacji Łodzi [Local Revitalisation Strategy], http://bip.uml.lodz.pl/_plik. php?id=40419 [accessed: 29.07.2016].

Lupton R. (2003), Poverty street: the dynamics of decline and renewal, Policy Press, Bristol.

Lupton R., Power A. (2004), What we know about neighbourhood change: a literature review, CASE report 27, http://sticerd.lse.ac.uk/dps/case/cr/CASEreport27.pdf [accessed: 29.07.2016].

Marcińczak S., Gentile M., Rufat S., Chelcea L. (2014), Urban Geographies of Hesitant Transition: Tracing Socioeconomic Segregation in Post-Ceausescu Bucharest, "International Journal of Urban and Regional Research", no. 38(4), pp. 1400-1417.

Marshall G., Roberts S., Burgoyne C. (1996), Social class and underclass in Britain and the USA, "British Journal of Sociology", vol. 47, no. 1, pp. 22-44.

Morris L. (1994), Dangerous Classes, Routlege, London.

Morris L., Scott J. (1996), The attenuation of class analysis: some comments on Marshall, Roberts and Burgoyne, 'Social class and underclass in Britain and the USA', "British Journal of Sociology”, vol. 47, no. 1, pp. 45-55.

Musterd S. (2002), Response: mixed housing policy: A European (Dutch) perspective, "Housing Studies", no. 17, pp. 139-144.

Natali L., Martorano B., Handa S., Holmqvist G., Chzhen Y. (2014), Trends in Child Well-being in EU Countries during the Great Recession, Innocenti Working Paper No. 2014-10.

Ourednicek M., Temelova J. (2009), Twenty years after socialism: the transformation of Prague's inner structure, "Studia universitatis babeş-bolyai. Sociologia", no. 1, pp. 9-30.

Petelewicz M., Rokicka E. (2014), Subiektywna jakość życia a status społeczno-ekonomiczny. Na przykładzie mieszkańców Łodzi, "Przegląd Socjologiczny”, vol. 63(2), pp. 143-161.

Polityka Społeczna 2020+ dla Miasta Łodzi - Strategia Rozwiazywania Problemów Społecznych [Policy 2020+ for the City of Łódż], http://www.uml.lodz.pl/get.php?id=15525 [accessed: 29.27.2016].

Potoczna M., Warzywoda-Kruszyńska W. (2009), Kobiety z łódzkich enklaw biedy. Bieda w cyklu życia i międzypokoleniowym przekazie, Wydawnictwo Uniwersytetu Łódzkiego, Łódź.

Sampson R. (2009), Disparity and Diversity in the contemporary City: Social (Dis)Order Revisited, "British Journal of Sociology", no. 60, pp. 1-31.

Schonkoff J., Philips D. (2000), From neurons to neighborhoods: The science of early childhood development, National Academy Press, Washington.

Sen A.K. (1999), Investing in Early Childhood: Its Role in Development, presentation at the Annual Meeting of the Inter-American Development Bank on "Breaking the Poverty Cycle: Investing in Early Childhood", 14 March 1999, Paris, http://www.iadb.org/sds/publication/publication_1394_e.htm [accessed: 29.07.2016].

Small M.L., Feldman J. (2012), Ethnographic evidence, heterogeneity and neighborhood effects after moving to opportunity, [in:] M. van Ham, D. Manley, N. Bailey, L. Simpson, D. Maclennan (eds.), Neighbourhood Effects Research: New Perspectives, Springer, Dordrecht.

Stănculescu M.S., Berevoescu I . (2004), Sărac lipit, caut altă viață!: fenomenul sărăciei extreme şi al zonelor sărace în România 2001 (Destitute, looking for a new life! Extreme Poverty and Poor Zones in Romania, 2001), Nemira, Bucharest.

Stébé J.M., Marchal H. (2009), Mythologie des cités-ghettos, Éditions Le Cavalier Bleu, Paris.

Sykora L. (2009), Post-Socialist Cities, [in:] R. Kitchin, N. Thrift (eds.), International Encyclopedia of Human Geography, Elsevier Press, Oxford. 
Temelová J., Novák J., Ourednicek M., Puldová P. (2011), Housing Estates in the Czech Republic after Socialism: Various Trajectories and Inner Differentiation, "Urban Studies", no. 48, pp. 1811-1834.

UNICEF (2005), Child Poverty in Rich Countries, Innocenti Report Card No. 6. UNICEF Innocenti Research Centre, Florence.

UNICEF (2010), The Children Left Behind: A League Table of Inequality in Child Well-Being in the World's Rich Countries, Innocenti Report Card No. 9. UNICEF Office of Research, Florence.

UNICEF Office of Research (2013), Child Well-being in Rich Countries: A comparative overview, Innocenti Report Card 11, UNICEF Office of Research, Florence.

UNICEF (2016), Fairness for Children: A league table of inequality in child well-being in rich countries, Innocenti Report Card No. 13, UNICEF Office of Research - Innocenti, Florence.

UNICEF (2016), The State of the World's Children 2016. A fair chance for every child, UNICEF, New York.

Wacquant L. (2007a), Urban Outcasts: A Comparative Sociology of Advanced Marginality, Polity Press, Cambridge.

Wacquant L. (2007b), Territorial Stigmatization in the Age of Advanced Marginality, "Thesis Eleven", no. 91, pp. 66-77.

Warzywoda-Kruszyńska W. (ed.) (1998), Żyć i pracować w enklawach biedy, Instytut Socjologii, Łódź.

Warzywoda-Kruszyńska W. (ed.) (1999), (Żyć) Na marginesie dużego miasta, Instytut Socjologii, Łódź.

Warzywoda-Kruszyńska W., Jankowski B. (2013), Ciagłość i zmiana w tódzkich enklawach biedy, Wydawnictwo Uniwersytetu Łódzkiego, Łódź.

Warzywoda-Kruszyńska W., Petelewicz M. (2010), Bieda $w$ dzieciństwie jako zagrożenie bieda i wykluczeniem, Wydawnictwo Biblioteka, Łódź.

Warzywoda-Kruszyńska W., Potoczna M. (2009), Kobiety z łódzkich enklaw biedy. Bieda w cyklu życia i międzypokoleniowym przekazie, Wydawnictwo Uniwersytetu Łódzkiego, Łódź.

Wilson W.J. (1987), The Truly Disadvantaged: The Inner-city, the Underclass, and Public Policy, University of Chicago Press, Chicago.

Wilson W.J. (2010), Why Both Social Structure and Culture Matter in a Holistic Analysis of Inner-City Poverty, [in:] D.J. Harding, M. Lamont, M.L. Small (eds.), Reconsidering Culture and Poverty, "The Annals of the American Academy of Political and Social Science", vol. 629, pp. 200-219.

\section{Zdegradowane sąsiedztwa miejskie w Polsce - ryzyko międzypokoleniowej transmisji ubóstwa i wykluczenia społecznego}

Streszczenie: Artykuł podejmuje problem biedy i deprywacji społecznej wśród dzieci, traktowany przez naukowców jako bariera rozwoju społeczeństwa obecnie i w przyszłości, co manifestowane jest w koncepcji państwa inwestycji społecznych. W artykule rozważamy tę kwestię w perspektywie efektów sąsiedztwa, ponieważ dorastanie w zaniedbanych społecznościach stanowi zagrożenie biedą w cyklu życia i w międzypokoleniowym przekazie. Ponieważ w Polsce brak jest danych statystycznych dotyczących małych obszarów miejskich, wykorzystujemy rezultaty socjologicznych badań (studium przypadku), przeprowadzonych w łódzkich zaniedbanych sąsiedztwach. Umożliwia to przedstawienie problemu biedy dzieci przez pryzmat osób jej doświadczających. Szerszy kontekst dyskutowanego problemu stanowią rezultaty analiz statystycznych dotyczących dynamiki biedy i deprywacji społecznej wśród dzieci w Polsce w porównaniu do innych państw członkowskich Unii Europejskiej. 
Celem tego artykułu, stosującego podejście interdyscyplinarne, jest uzyskanie lepszego zrozumienia zjawiska biedy i deprywacji społecznej wśród dzieci w Polsce i jego dynamiki. Argumentujemy, że temporalne wzory biedy dzieci i deprywacji społecznej mogą być odmienne w różnych społecznościach, np. w „całym” społeczeństwie i w biednych społecznościach mieszkających w zdegradowanych sąsiedztwach. W konkluzji stwierdzamy, że mimo znaczącego zmniejszenia zasięgu biedy i deprywacji społecznej wśród dzieci, dokumentowanego w statystyce publicznej, Polska jest nadal krajem, w którym bieda dzieci jest poważnym problemem i gdzie dzieci dorastające w zaniedbanych miejskich sąsiedztwach są pomijane.

Słowa kluczowe: efekty sąsiedztwa, bieda i wykluczenie społeczne dzieci, nierówności społeczne wśród dzieci

JEL: R23

\begin{tabular}{|l|l|}
\hline \multirow{2}{*}{ OPEN ACCESS } & $\begin{array}{l}\text { C by the author, licensee Łódź University - Łódź University Press, Łódź, Poland. } \\
\text { This article is an open access article distributed under the terms and conditions } \\
\text { of the Creative Commons Attribution license CC-BY } \\
\text { (http://creativecommons.org/licenses/by/3.0/) }\end{array}$ \\
\cline { 2 - 2 } & Received: 2016-08-31; verified: 2017-01-11. Accepted: 2017-07-31 \\
\hline
\end{tabular}

